\title{
Plural policing, the public good, and the constitutional state: an international comparison of Austria and Canada - Ontario
}

\section{Bas van Stokkom \& Jan Terpstra}

To cite this article: Bas van Stokkom \& Jan Terpstra (2018) Plural policing, the public good, and the constitutional state: an international comparison of Austria and Canada - Ontario, Policing and Society, 28:4, 415-430, DOI: 10.1080/10439463.2016.1205065

To link to this article: https://doi.org/10.1080/10439463.2016.1205065

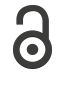

(c) 2016 The Author(s). Published by Informa

UK Limited, trading as Taylor \& Francis Group

曲 Published online: 11 Jul 2016.

Submit your article to this journal $₫$

Wll Article views: 931

Q View related articles ए

View Crossmark data ¿ 


\title{
Plural policing, the public good, and the constitutional state: an international comparison of Austria and Canada - Ontario
}

\author{
Bas van Stokkom and Jan Terpstra
}

Faculty of Law, Radboud University Nijmegen, Nijmegen, The Netherlands

\begin{abstract}
For the past two or three decades many jurisdictions have experienced a pluralisation of policing. In addition to the regular public police, in most countries new providers have become involved in policing public and semi-public places. This paper deals with the differences in the ways that plural policing and its consequences are defined and assessed in different countries. The paper focuses on two countries that differ considerably in the impact of neoliberalism, Austria and Canada Ontario. In these countries different discourses are used to assess plural policing and its potential negative impact. In Canada the public good is the central concept in discussions of plural policing. This often refers to instrumental goals such as value for money and service delivery to consumers. In Austria plural policing is generally discussed in terms of the tasks and position of the state, the monopoly of violence, and by referring to constitutional and fundamental legal perspectives. This study shows that international comparative research on (plural) policing cannot be based on the tacit assumption that central concepts such as public good have universal relevance. On the contrary, these normative concepts are highly context dependent, an important conclusion for future international comparative research on policing and security.
\end{abstract}

\section{ARTICLE HISTORY}

Received 18 November 2015 Accepted 17 June 2016

\section{KEYWORDS}

Plural policing; public good; international comparison; neoliberalism

\section{Introduction}

Since about the late 1980s, almost throughout the world, there has been a turn towards plural policing. It is not only the regular police, but now also other providers of policing who patrol the public and semi-public places. A recent international comparative study showed that although this is an international development, nevertheless there are important differences in its process and outcomes (Terpstra et al. 2013).

This paper deals with different ways in which plural policing and its main consequences are perceived and defined. In Anglo-Saxon countries it is quite usual to use the notion of the public good to evaluate plural policing and its main social consequences. The dominance of the neoliberal and the related new public management (NPM) discourses contributed to the adoption of highly economic and instrumental interpretations of the concept public good, for instance in terms of 'consumer service delivery' (Loader 2000, Newburn 2001). The idea of policing as a public good has been studied by several leading theorists (Shearing and Wood 2003, Crawford 2006, Loader and Walker 2007). For example, in their Civilizing Security (2007), Loader and Walker argue for security and policing as a 'thick' public good rather than the usual 'thin' economic and instrumentalist interpretations. Because 
of this public good, the state is seen as indispensable for anchoring security and policing. Although this analysis is very important in understanding the debate about plural policing and security, we believe that the concept of the public good is highly specific for certain political and cultural contexts. We expect that other concepts and notions tend to be used in continental-European countries that are highly dependent on their specific cultural, historical and political context and history.

For that reason, in this paper we use a comparative approach to understanding the different discourses that are used to define and discuss plural policing and its consequences. That such an approach has not been adopted hitherto reflects the lack of attention to the context-dependency of the notion of the public good in research on policing.

In this paper we study two countries, Austria and Canada, that have contrasting discourses on (plural) policing. These two countries differ in the impact of neoliberalism. Despite the fact that neoliberalism has also had some influence in Austria, in general the country holds to state centrism, especially where policing is concerned. Canada played a leading role in the introduction of neoliberalism in the governance of security. The central question is: In what different ways are plural policing and its consequences perceived and defined in these two countries? What are the underlying views and values in these different evaluations? The differences may be relevant to understanding the emotional and political resistance to pluralisation and differences in the willingness to privatise policing and security. Understanding these differences in the ways that the pluralisation of policing and security is perceived and discussed is fundamental to future international comparative research on this topic.

In this paper we first discuss the methodology of our international comparative research (Section 2). Next we deal with the developments in plural policing in Canada (Section 3) and Austria (Section 4), after which we present an analysis of the main discourses about plural policing used in Canada (Section 5.1) and Austria (Section 5.2). Both discourses represent different sets of values and perspectives, meaning that the two countries differ in the way plural policing is generally assessed. Finally, we contrast the two countries and deal with some consequences of our analysis for international comparative research (Section 6).

\section{International comparison: methodological issues}

This paper builds on a comparative study conducted in five different countries, which focused on the similarities and differences in plural policing between the countries. In each of the countries we studied relevant documents and interviewed 25 key persons (Terpstra et al. 2013). In this paper we try to understand the different terms in which plural policing and its (negative) impact are perceived, discussed and evaluated. We expect this to have a huge impact on the degree and nature of both the adoption of plural policing and the resistance to it. To understand these differences, here we concentrate on two countries, Canada and Austria. In many respects these two countries represent contrasting positions. In Canada, neoliberalism has become highly influential since the mid1980s (Clark 2002), including policing. Private security companies make a considerable contribution to policing and security in (semi-)public places (Rigakos 2002, Rigakos and Leung 2006). In view of the significant differences between the provinces in Canada, the study concentrated on Ontario. Since the 1980s Ontario has generally been considered to have a strong doctrinaire neoliberal policy, in contrast for instance to Quebec, which represents a more pragmatic and state-oriented reform policy (Clark 2002, Gattinger and Saint-Pierre 2010).

Austria can be seen as an example of continental-European countries where the state still retains much of its strong position (despite the fact that neoliberal measures such as privatisation have also acquired some support). Austria has a somewhat contradictory position. On the one hand, it has also experienced a pluralisation of policing (although this process started relatively late and is not very extensive compared with other European countries; CoESS 2011, Terpstra et al. 2013). On the other hand, policing by non-police providers in Austria is often seen as an anomaly: the service should actually be provided only by the regular (state) police. 
International comparative studies of policing and criminal justice often raise several problems. Researchers often refer to two of these (Jones and Newburn 2006). First, such studies often have to cope with a lack of reliable empirical data for comparison between different jurisdictions. Secondly, these studies encounter difficulties due to differences in formal rules, procedures and legal terminology. For instance, to understand differences in plural policing between Austria and other countries, it is relevant to know that the legal concept of public space in Austria does not depend on property rights, as is the case in most other countries, but on accessibility to the general public (Fuchs 2005). Unfamiliarity with this aspect may result in misunderstandings and unjustified generalisations about the role of the police in supervising private property. Although both a lack of empirical data and legal differences can complicate international comparative studies, an underlying complex of emotional, historical, cultural and political factors can make it even harder to draw valid comparisons. One of the problems is that these factors may be so self-evident to members of national cultures and communities, that often they are not even noticed. For instance, as Nelken (1994) argues, differences in government policy and the performance of major institutions may depend on different patterns of trust, either real or imagined, between citizens and the state. For relative outsiders it may be difficult to comprehend the largely unwritten and informal context. Traditions, sensitivities, emotions and hidden interests may have a strong, but mainly hidden impact in a certain national context. In Austria, for instance, there is a strong emotional resistance to plural policing, partly based on collective memories about what happened in the country in the years before the Second World War (Terpstra 2015). Although these memories are still present in the collective awareness, they are only rarely referred to in public documents or debates.

In the present study we have tried to overcome these problems by not having the research in the separate countries done by researchers from the countries concerned. Such an approach may not only make it difficult to share a common focus, it may also raise the risk that elements that are tacit and self-evident to those who study their own country, will remain unremarked. We therefore decided to do the research in each of the countries ourselves.

The research was based upon a study on the pluralisation of policing in five countries: Belgium, Austria, England \& Wales, Canada - Ontario, and the Netherlands (Terpstra et al. 2013). ${ }^{1}$ In this study we dealt with diverging types of policing employees concerned with security and safety issues in the (semi-)public space. In each country we collected information about forms of plural policing and the underlying processes and factors. First, relevant documents were studied like legal arrangements, policy documents, newspaper articles and scientific publications. Secondly, in each country we interviewed some key persons (in sum 25), working in different positions, like officials of the national government, representatives of the local authorities, the regular police, and nonpolice providers of policing. The information gathered was reported in country reports. ${ }^{2}$

Sections 3 and 4 are based on this international comparative study (interviews with key persons, local case studies and the analysis of policy documents) (Terpstra et al. 2013). The arguments in Section 5 are built around an additional and complementary review of country-specific literature. To this end, we focused particularly on long-term political and cultural developments in Austria and Ontario, tracing factors that potentially contributed to neoliberal policy-justifications and 'traditionalistic' resistance against neoliberal policies.

This approach takes a lot of time: documents must be studied in detail, interviews were done by ourselves, and we took the time for observations and local case studies. The process demands that researchers have a mastery of the language concerned, and in some cases they can understand local dialects. It is also necessary to delve into national cultures and history. In spite of the fact that this approach takes a lot of time, we believe it is necessary to achieve what Nelken (2002, p. 180) summarised as: 'how can we be sure that we are comparing "like with like", both in terms of the distinctive elements (-) and in terms of its place in the larger culture?'

The comparative interpretative approach used here, implies that we should be sceptical about facile generalisations and assumed universal developments in policing and security, such as the advance of neoliberal governance and rolling back the state. Nation-states are differently placed in 
their dealings with or being subjected to transnational developments, such as the move to neoliberalism, and respond in different ways (Clark 2002). Through comparative research we can learn about (local) processes of 'adjustment, articulation, ambivalence or resistance' and make sense of the incongruence of meanings and their cultural embeddedness (Nelken 2010, p. 43).

One of the main tasks of international comparative approach is to make cultural biases visible and break out of what Van Swaaningen (2011) and Nelken $(2010,2011)$ called the ethnocentric vision of crime and its control. This may result in the belief that the researchers' own local arrangements are the general rule. However, in much of the international research on policing and security the problem is not so much ethnocentrism, but the dominance of Anglocentrism. Not only do many researchers in the U.S. and England (presumably implicitly) assume that their arrangements and problems are universal, this dominance is so strong that even researchers from other countries may be inclined to accept theories and interpretations from the English-speaking world as if they also apply to their own situation, even if this may be unclear or questionable. Researchers from non-Anglophone countries may be driven towards this 'international', but in fact Anglo-perspective, because in some European countries the NPM-absurdity exists that only English-written publications (and not publications in the local language) count in the universities' performance measurement systems. To promote acceptance of their papers in international journals, researchers may feel the need to adapt their analyses so that they can be easily incorporated in the perspectives of English and American reviewers.

This is even more important for the issue considered here. The dominance of the English-speaking academic world is not only a matter of language and culture, since the 1980s it has also involved the world-wide dissemination and overwhelming acceptance of the neoliberal discourse (Harvey 2005). By contrasting Austria and Canada, we aim to show that the public evaluations of and debates on plural policing embrace more than just neoliberal-inspired interpretations of the public good.

\section{Plural policing in Canada - Ontario}

Since the 1980s Canada has been powerfully influenced by the neoliberal discourse, placing great emphasis on budget cuts and privatisation (Clark 2002). There are significant differences between the provinces, with Alberta and Ontario being instances of ideological neoliberalism and Quebec presenting a 'neo-statist' reform policy (Clark 2002, Gattinger and Saint-Pierre 2010). The growing dominance of neoliberal discourse led public services to be depicted as monopolistic, inefficient and unresponsive. This also applied to policing services, which were redefined as marketable commodities. 'The previously insular and militaristic organisational culture of public policing has been colonized by business concepts, values and terminology. [...] Police are encouraged to see themselves in the "business" of supplying policing services to clients, customers and consumers' (Murphy 1998, p. 17).

Subsequent governments promoted flexibility and consumer choice in the management of service-delivery functions, thereby overcoming the perceived traditional bureaucratic rigidities. Central to these neoliberal programmes is the use of contracts: the aim is to create a business ethos and competition and to establish internal quasi-markets that allow consumers to purchase services (O'Connor and Ilcan 2005, p. 18). One consequence of this approach was the outbreak of 'aggressive bidding wars' for policing contracts (Murphy 2002, p. 18).

Canada has about 350 providers of police forces, including the Royal Canadian Mounted Police (RCMP), the Ontario Provincial Police (OPP), and large numbers of regional and municipal forces. According to Rigakos and Leung (2006), the strong growth of private security is mainly motivated by reference to the increasing costs of the public police. Budget cuts and rationalisation led to the formation of regional police units, a process of scaling-up that also occurred in Ontario (Lithopoulos and Rigakos 2005).

The police system in Canada is decentralised, but police officers at the local level may belong to a provincial or national police force. After the expiry of a contract, the municipality may contract 
another police force. A municipality can even contract several police forces within its territory. As a result, a mosaic of police forces arose at the municipal level. The forces vary greatly in terms of size and budgets and hence, the classical formula of 'single jurisdiction - single police service' - nowadays has little significance (Rigakos and Leung 2006).

The Police Services Act of Ontario (1990) states that the municipality is responsible for the police function. The municipality itself has to pay for the police force(s) and has to decide whether to maintain its own police force or to contract police work externally. This contracting system is supposed to motivate municipalities to explicate their needs for policing services and to terminate services in case of poor quality (Law Commission 2006, p. 51).

The OPP is involved in more than 300 contracts in which it provides police services to municipalities. This contracting system led to a police market within the public sphere, whereby the police force defines itself as a supplier of products; the police adopted a commercial language and management style.

Each municipality in Ontario has a Police Services Board, which makes police policies, sets priorities, appoints staff, hires the police chief and deputy chiefs, and establishes guidelines to deal with citizen complaints. The operational management of the municipal police force is the responsibility of the service provider. Boards should serve as a buffer against politics, to warrant the independence of the police (Law Commission 2006, p. 85).

In Canada, large numbers of agencies and professions are involved in the surveillance of public places. First, there are government-related professions including special constables and by-law enforcement officers. Special constables (also called 'parapolicing officers'), for example, work on university campuses (Rigakos and Leung 2006). They are professional, sworn peace officers, appointed by the local police services boards but employed by their own organisation. In Ontario, special constables may have full police powers for their own territory; they can arrest and detain citizens, without intervention or support by the regular police, except in case of more serious offences (Carroll 2004).

By-law enforcement officers may enforce municipal laws relating, for example, to parking, noise nuisance and control of animals. The powers and equipment of by-law officers vary from municipality to municipality. By-law officers are cheaper than the regular police and can work flexible hours (but not 24/7) (Murphy and Clarke 2005, p. 222, Law Commission 2006). Canada also has several (quasi-) public policing organisations, like the Corps of Commissionaires (a non-profit organisation of former members of the armed forces) and paid duty policing (sworn police officers providing services to private clients, such as the organisers of events and festivities).

The Canadian private security has grown strongly during the past few decades. The private security sector is almost twice as large as the regular public police (Law Commission 2006, The Expert Panel 2014, p. 36). The private security sector provides many services related to enforcement and crime control. In Business Improvement Areas, private security guards are contracted to patrol the streets and fight antisocial behaviour (Law Commission 2006, Rigakos and Leung 2006). For example, the security company Intelligarde presents itself as 'the law enforcement company' (Rigakos 2002).

Private security guards have the same powers as ordinary citizens (Law Commission 2006). The provincial Trespass to Property Act permits the arrest of suspects and their removal from the private domain. Security guards are permitted to stop, question, remove or secure persons engaging in problematic behaviour and committing offences on private property. Unlike the actions of police officers, the actions of private security guards are not closely regulated by law. In practice, security guards can remove citizens from the terrain where they work without giving any reasons for doing so.

According to the Law Commission (2006, p. 103), self-regulation in the private security branch is of poor quality. In 2005 the Private Security and Investigative Services Act introduced several changes in Ontario. A mandatory licence was established in 2008 , including requirements related to training and insurance. 
The protection of citizens from security guards is a hot issue in Canada. The regulation of private security is often seen as inadequate. Security guards may operate as police officers, although they have no special powers. They have the discretion to conduct intrusive surveillance and publish bans on people in a manner that is not available to the public police, which raises many questions about democratic accountability. Many law scholars believe it is unacceptable that the public police have to render account to democratic bodies, while security guards are not subject to such oversight (Burbidge 2005, Law Commission 2006, p. 37).

\section{Plural policing in Austria}

Austria has two kinds of police forces. The Federal Police (Bundespolizei) was set up in 2005, with most of its 23,000 officers working in one of the almost 1000 police districts. In addition, 37 municipalities (mainly in Tyrol and Vorarlberg) have their own (often small) municipal police forces. The number of municipal police forces has been decreasing since the Second World War, mainly because municipalities have to fund such forces themselves. So-called Statutarstädte, which in general are the large cities like Vienna, Graz, Innsbruck, Salzburg or Linz, are forbidden by statute from establishing their own municipal police force. This prohibition dates from the 1920s, a period of great political unrest and the rise of National Socialism in Austria (Beller 2006, Terpstra 2015). The fear persists to this day that (as happened in those years in Austria) police forces might be set against each other and play a political role (Wenda 2013).

Two types of non-police providers of policing were introduced in 2007 at the local level in Austria. First, the governments of the Statutarstädte created local organisations with uniformed officers to patrol the public space, called Ordnungswache or Public Order Guards. The formal powers of these municipal officers are quite minimal; they do not go beyond what is called Everyman's Right (Jedermannsrecht). Only in the city of Graz do these municipal officers have the formal power to impose fines for certain infringements.

Several factors contributed to the introduction of these local Public Order Guards. Despite the relatively low level of crime in Austria, public safety became an important political issue in the 1990s. Local governments felt the need for visible measures to do something about it. For about a decade now, the distance between the (federal) police and local communities has been growing. The priorities of the police shifted to national issues and fighting crime. In the years following the 2005 police reform, about 120 police offices were closed, causing a local 'security vacuum'. Finally, because the Statutarstädte were legally not permitted to maintain a municipal police force, the only solution for the perceived patrol deficit in the public places was to create their own municipal surveillance organisations (Wenda 2014).

Political circumstances are also relevant to understanding the introduction of the municipal Public Order Guards. The Freedom Party of Austria (FPÖ), a far-right political party, in particular emphasised public safety as a major problem, demanding tough measures against crime and disorder. The FPÖ had a strong position in the city of Graz, which makes it easier to understand why the first Ordnungswache was established there. The Public Order Guards encountered much opposition, the main argument being that policing should be the responsibility of the police alone. This view is motivated by both constitutional-legal arguments and by reference to the principle role of the state in policing (Terpstra 2015). Despite this strong orientation to the state, in practice many of the large cities now have Public Order Guards. The combination of the political pressure to do something about public safety and the 'security vacuum' left by the regular police leads city governments generally to support the establishment of Public Order Guards. However, as a result of the strong orientation to the regular police, the Public Order Guards generally do not have specific powers and are not permitted to carry weapons. Much discussion is also held about the municipal guards' uniforms, which should not appear similar to those of the regular police.

Secondly, in Austria for about 15 years, now, private security has gained an increasingly visible role in the (semi-)public space (Fuchs 2005). Since about 2005, a small number of municipal governments 
(40-50) have contracted private security guards to work in the public places. These cities, most of them of medium size, do not have their own municipal police force or Public Order Guards; they contract private security companies for reasons that are largely comparable to those of the larger cities that established Public Order Guards: to meet the need for more visible uniformed patrol in the streets and to fill the gap in surveillance and patrol left by the federal police. The formal powers of these contracted private security guards are minimal, being only those of the Everyman's Right. Local case studies show that the reasons why these local governments contracted private security guards were often highly pragmatic. Often as a result of some local incident that created a lot of political and social unrest, the local governments needed more officers to patrol public places on a very short term. The only way to realise this was by contracting private security. Once they had some experience with these officers, they decide to continue this practice, generally also for pragmatic reasons. In comparison with Public Order Guards or municipal police this strategy is much cheaper and gives more room for flexibility. Still, this privatisation is generally seen as an undesirable development (Terpstra et al. 2013).

The legal regulation and control of private security in Austria is rather poor. There is no legal set of quality standards for private security (Fuchs 2005, pp. 205-214, CoESS 2011). There are no general rules for the government agencies' contracts with private security companies (Stolzlechner and Horvath 2009). In addition, there is no specific regulation of the possession of firearms by private security officers. The general rules of the Arms Act (Waffengesetz) also apply to private security workers. A licence may be provided, given the specific risks of working in the security sector (Fuchs 2005, pp. 214-215). As a consequence, in Austria about 600 private security workers are permitted to carry weapons (CoESS 2011), including their work in the public places. This is in contrast to the municipal Public Order Guards, who are always unarmed and (for reasons that in the Austrian context are perceived as absolutely fundamental), must avoid any association with the police.

In Austria there is a widespread reluctance to accept the pluralisation and privatisation of policing. A dominant view is that the regular, federal police should be responsible for all policing tasks and that other agencies, public or private, should not be involved. Plural policing is often seen as a highly politicised and sensitive issue with very different views voiced by the political right and left. Important elements of this emotional framing of plural policing are derived from Austrian political history, especially the age of the serious and often violent political clashes in the 1930s (Beller 2006, pp. 212-230). For that reason it is still not unusual to associate private security with the armed extreme political groups of those years. This also explains why Austria, without much debate, continues to hold on to Art. $78 \mathrm{~d}(2)$ of the Constitution, which - as mentioned - states that the larger cities (Statutärstädte) are not permitted to have their own municipal police force.

Given this reluctance, it is quite remarkable that pluralisation and privatisation still continue, and that at the time of writing, Austria has not yet established a specific legal framework to regulate private security. In some respects it appears that the strong orientation to the state results in a lack of awareness of the ongoing privatisation of policing. Maybe the taken-for-granted position of the state is so strong and self-evident that is looks as if there is a 'denial' of the ongoing pluralisation process. A more detailed study would be necessary to establish the factors underlying this lack of a legal regulatory framework. Indicative maybe is that the public debate in Austria about the pluralisation of policing concentrates on the fundamental question of whether there should be any room at all for non-police wardens and patrol officers in the public space (cf. Fuchs 2005). Much less attention is paid, for example, to questions concerning the conditions that non-police policing in public space should meet to guarantee the legal protection of citizens' rights.

\section{Discourses on plural policing}

The two countries not only differ in their systems of plural policing, but also in the way the pluralisation of policing is perceived and discussed. These differences are closely related to historical, cultural and political circumstances in the two countries. One of the main factors is the difference in the 
impact of neoliberalism, with many consequences for the dominant views on the role of the state and of the market. Once again, first we deal with Canada - Ontario, followed by an analysis of Austria.

\subsection{Canada: discourses on the public good}

Since the 1990s Canadian governments, both federal and provincial, have acted decisively to bring deficits and debt under control. Government policies aimed at retrenching the state include: programme cutbacks, downsizing of public sector employees and deregulation of certain sectors (Clark 2002). Alternative service-delivery systems were introduced, which challenged traditional hierarchical public service structures and facilitated outsourcing. Political elites succeeded in transposing a new, neoliberal orthodoxy onto existing legacies of public service (Clark 2002).

In Canada the provinces differ in the incorporation of public service reform into the broader neoliberal agenda of slimming the state. Ontario is a clear instance of ideological neoliberalism, whereas Quebec presents a neo-statist reform profile (Gattinger and Saint-Pierre 2010). In Ontario conservative governments extolled the virtues of a neoliberal economy and introduced populist policies (a prime example being the party's manifesto 'Common Sense Revolution' in 1995) (Clark 2002, p. 785).

In recent years, federal policies have focused on work reorganisation, downsizing, and attacks on the labour rights of unionised public sector workers. In Ontario, neoliberal policies and post-2008 austerity set the stage for reduced spending and wage freezes for workers in the public sector. In Toronto, Rob Ford was elected mayor in 2010 after running a populist campaign pledging to keep taxes low and eliminate wasteful spending at city hall (the 'gravy train') (Thomas and Tufts 2016).

In the context of these neoliberal policies, policing is increasingly treated as a commodified object (Law Commission 2006, p. 37). The interconvertibility of private security and paid duty policing in public space generated intense competition and commercialisation (Rigakos and Leung 2006). This also happened in tender procedures for contracting out, both between public police forces and between security companies and the public police. A clear distinction between private and public policing is hard to make in Canada. According to the Law Commission (2006) the public police no longer have a monopoly on the provision of security services (p. 8). In this context - an open market for policing services in which public and private sectors compete for business - it comes as no surprise that network, nodal governance and multilateralisation theories became influential. These theories postulated that the state had lost its a priori special position: just 'one node among many' (Shearing and Wood 2003, Shearing 2005). As early as 1981, Shearing and Stenning pointed out that the rise of private policing institutions could be described as a 'quiet revolution in policing and social control systems' (1981, p. 193).

Although plural policing is well-established in Canada, still it is not uncontested. Two debates may illustrate this. Both concentrate on different interpretations of policing as a public good. The first debate revolves around the question whether the public police should be conceived as businesslike, selling marketable products. The second concentrates on the governance and accountability of both public and private policing.

\subsubsection{Public police: business-like?}

Two competing conceptions of the public good and public service emerged in debates about contracting out, marketisation, budget cuts and public sector restructuring (McDonough 2006, p. 631). First, a neoliberal perspective which ties the public good to the quality of services provided with maximum efficiency; quality can only be achieved by creating market competition and consumer choice. Secondly, in response to the neoliberal perspective, a 'traditional' approach, in which the public good is associated with duties to serve the community (see also Murphy 2002). The police slogan 'to serve and protect' places great stock on values such as accountability, impartiality and loyalty. In Canada, the public good is generally discussed in terms of service delivery. The neoliberal perspective is connected to the public good, understood in a strictly economic way: the police should improve the efficiency and effectiveness of their services. On the other hand, the traditional 
perspective is communitarian in nature: the police should be loyal to the democratic community, upholding the principles of the legislatures and the Charter (Robertson 2012).

Since premier Mike Harris acclaimed a 'Common Sense Revolution', neoliberal strategies have become very influential. The OPP was reinvented according to his agenda, reinforcing a marketbased ethos in the governance of the province. The government attempted to reduce the debt load and a two-pronged strategy was implemented to realise this goal: to centralise effectiveness standards, and to shift decision-making to the local level. The OPP was re-imagined as a 'business' and the development of Policing for Results schemes represent an effort to 'tap into' its market (Wood 2000, p. 269).

These market strategies introduce values - such as cost-benefit, efficiency and consumer satisfaction - that conflict with the historical character of the public police as a legally bound public service (Murphy 1998, 2002). Many police leaders tend to oppose the new business-like discourses, especially with regard to marketplace competition among public police forces. Murphy's interviews showed that police leaders and executives generally evaluate service competition negatively. Common criticisms are: the uneven and unfair nature of the competition (smaller municipal services are in a weaker position), the extraordinary time and resources needed to prepare and manage competitive bidding, and morale problems among recruited police officers. 'Most observed that the competitive process had undermined police solidarity and the collective and collaborative spirit that has traditionally been regarded as a necessary and important policing value' (Murphy 2002, p. 12). Only a quarter of the respondents were in favour of competition. Nevertheless, Murphy's study showed that about $40 \%$ believed that policing should be run more like a business and less like a public service.

Many police chiefs champion change and reform, whereas rank and file officers and their associations adhere to traditional occupational patterns. This may explain conflicts between police associations and high-profile, change-oriented police chiefs (Murphy 2002, p. 15, also Murray 2004). Paradoxically, the corporatisation of police management in Canada reinvigorated trade union consciousness and organisation. Rather than managerial principles filtering down to the lower ranks, business values are resisted at the street level (De Lint 1999, O'Malley and Hutchinson 2007). Apparently, the possibilities for transferring business standards to 'street cops' are limited.

Recently many programmes have been initiated to reduce the 'exploding costs' of policing by focusing on core duties, privatisation and contracting out. The federal government tends to interpret the 'traditional' occupational patterns of the public police as an obstacle to reforming police organisations (see Ruddell and Jones 2014). In this context, the public police are often accused that they 'deny reality' and are summoned to abandon their 'defensive posture' (see Marks 2007).

\subsubsection{Accountability of public and private policing}

The second debate in Canada focuses on the governance and accountability of both public and private policing. Many academics and lawyers criticise the fact that protections in the Canadian Charter of Rights and Freedoms have only been applied to governmental activities and not the private sector: 'the legal environment generally provides much greater latitude for coercive and intrusive policing activities of non-state authorities than for those of state authorities' (Hermer et al. 2005, p. 31). It is deemed unacceptable that private security is not subject to comparable democratic governance and accountability as the public police, especially because public and private police often perform the same policing functions. Comprehensive and effective democratic governance and accountability are seen as necessary to both public and private policing (Burbidge 2005).

The Law Commission (2006) deplores that the governance and accountability of policing still reflect the public-private dichotomy: 'The challenge and opportunity for legislators and policy makers is to consider governance and accountability mechanisms that deal with policing in all of its manifestations' ( $p$. Xv). The Law Commission believes that citizen involvement in boards and oversight commissions is an essential component of policing as a public good (p. 142). Adequate public participation is needed in both complaints procedures and policing policy decisions. 
Although there is general agreement on the need to strengthen both the accountability and governance of policing, and the involvement of civilians in oversight bodies, there is still a lot of debate about whether private and public policing officers should perform the same tasks and duties. Protagonists of nodal governance claim there are no longer clear distinctions between the roles and remits of 'public' and 'private' police. They assume that the prioritised role of public police is dispensable and outlived, and that private and public policing should stand side-by-side on an equal basis. The two systems should even compete to raise professional quality and effectiveness (Hermer et al. 2005, p. 73).

However, others point out the differences and conflicting ambitions between public and private policing. They stress that the duties, powers, qualifications and training of both bodies are not compatible and that the rationale for public policing is to protect democratic governance, 'Bearing in mind that private security personnel serve primarily their private masters, we must ensure that they do not pose a threat to public policing' (Cukier et al. 2003, p. 257, see also Kinnear 2000). Many police (union) leaders conclude that security guards should defer to the higher authority and expertise of the public police, and that policing responsibilities should not be shared with private security organisations (Murray and McKim 2000). On the other hand supporters of nodal governance label this resistance as the ideology of 'police independence', according to which any reform initiative is suspect as undermining police authority (Stenning and Shearing 2005, p. 173).

In conclusion, in Canada the normative and political debates on plural policing concentrate on policing as a public good. On the one hand, there is the neoliberal belief in the effectiveness and efficiency of the policing market. On the other, there are two interpretations of the public good to mitigate the perceived negative effects of commodified and plural policing: the public ethos of policing services to the community, and the public good understood as the importance of democratic governance and accountability.

\subsection{Austria: state-centeredness and legal discourse}

Although Austria has also experienced the pluralisation of policing for roughly a decade now, nevertheless the dominant view is that only the state should be responsible for policing and security. The rather negative evaluations of plural process are closely related to a strong belief in the state, to the dominance of constitutional and legal views, as well as the relatively late and minor impact of neoliberalism.

After the dark ages of the 1930s and 1940s (with their violent conflicts between militia aligned with the main political parties; Blasi 2015), the Dollfuss dictatorship, the integration into the Third Reich, and the terror of the Second World War (Beller 2006), Austria was confronted with the need for stability, social peace and lawfulness. From this perspective, the creation of the Austrian conservative and corporatist welfare state (Esping-Andersen 1990) must be seen as a huge success. This welfare state has been built up since the post-War years with the support of both the Social-Democratic Party (SPÖ) and the (conservative) Christian Democratic Party (ÖVP). The Kreisky era, named after the social-democratic chancellor who governed between 1970 and 1983, is often seen as a period that made of Austria an 'Island of the Blessed' (Beller 2006, pp. 271-286), with a high level of social partnership, consensus, prosperity and social peace. Whereas in the 1980s many European countries were confronted with an increasing influence of neoliberalism, the so-called Austro-Keynesian approach was maintained in Austria (Tálos and Fink 2001, Beller 2006). Nevertheless, the general consensus of Austrian politics started to erode in the mid-1980s.

In 1995 membership of the EU marked an increasing influence of neoliberalism. It contributed to the first wave of neoliberal measures in Austria, such as the privatisation of some large state-owned industrial companies and of several important public service organisations (such as public transport and the postal service). By and large, however, the Austrian welfare state remained intact (Tálos and Fink 2001). 
In the year 2000 the social democrats lost their position in government (which they had retained since 1945 with only one interruption). A coalition of ÖVP and FPÖ introduced a neoliberal agenda in Austria. Neoliberal ambitions already known from many other countries dominated the government's policies between 2000 and 2006, such as 'more market, less state', 'more individual responsibility', reduction of government budgets, and a concentration of the state on its 'core tasks' (Tálos 2001, Tálos and Fink 2001, Kreisky 2002).

Although Austria has been faced with neoliberalism since that time, in many respects the dominance of the state and corporatist traditions is still very strong. In 2001 Tálos and Fink concluded that there is a clear 'path dependency' in the development of the Austrian welfare state. Despite neoliberal measures, compared with many other countries, the impact of the neoliberal discourse is still limited in Austria. Some observers even think that neoliberalism is almost non-existent in Austria, and has only a very minor relevance (Rauscher 2011).

The strong belief in the state, the collectivism and prevailing legal perspective can also be found in the perceptions and assessments of plural policing in Austria. Neoliberalism exerts an even smaller influence on policing and security, where the dominance of the state goes largely unquestioned. Privatisation of policing and security is generally seen as objectionable or only acceptable within very strict limitations. Given the minor importance of neoliberalism in Austria, it comes as something of a surprise that notions of NPM, more or less akin to neoliberalism, were still picked up, even with regard to policing and security. For instance, in some of its policy papers the Ministry of the Interior presents itself as a 'client-oriented institution'. Based on notions of performance management, the Ministry stated as its target that it wants to make Austria 'the safest country in the world' (Bundeskanzleramt 2013 , p. 10, Bundesministerium für Inneres 2015, p. 13). These NPM notions seem hard to reconcile with the usual legal and constitutional perspectives. It seems that these concepts mainly operate as an imitated jargon, used for presentational strategies without fundamentally changing the traditional statist and legalistic outlook.

Several elements are relevant to an understanding of the dominating perspective on plural policing in Austria. First, the state is still seen as the obvious central actor in policing and security. It is also defined as being responsible for the public safety of the country. A constitutional-legal view of the tasks of the state means that policing and security are seen as the exclusive domain of the state. Although Austria has a certain level of pluralisation of policing and has multi-agency security partnerships at the local level (Stolzlechner and Horvath 2009, 2010), the Ministry of the Interior still defines itself as 'the security provider number one in Austria who has the supreme responsibility for the security of our country and as a consequence is the most important guarantee for social peace in our society'. Although the Ministry defines itself as being ultimately responsible for public safety, it realises that it is not able to do this completely on its own. However, in the Austrian context a holistic or 'integrated' approach to security does not mean collaboration with non-state partners, but between the Ministry and other public administrative or statist institutions ('gesamtstaatlich') (Sandrisser 2015).

A second important element in the Austrian discourse about (plural) policing is the monopoly of violence (Öffentliche Sicherheit 2002, Fuchs 2005, 2012), a principle often referred to in this context. Under all circumstances the legitimate use of coercion should be retained in the power of the state. In Austria the main argument against plural policing is the fear that this process might undermine the monopoly. In an earlier paper we suggested that this deep-rooted feeling is still reflective of the turbulent situation in Austria of the 1930s, when the state proved unable to preserve this monopoly, and violent conflicts between militias put an end to the democratic republic (Terpstra 2015).

In addition, in Austria human and fundamental rights are seen as the principle basis of security policy: 'The individual with his/her fundament rights and needs must have a central position in any decision about security' or 'The republic of Austria is built upon solid values. The fundamental values present the basis of political decisions and as a result the fundament for Austrian security policy'. Human rights, principles of pluralistic democracy, constitutional guarantees ('Rechtsstaatlichkeit'), and the strict division between different authorities are presented as the fundamental values of 
Austrian security policy (Bundeskanzleramt 2013, pp. 4 and 9, Bundesministerium 2015, Sandrisser 2015). Because these values and principles are defined as properties of the state, this is seen as a warning not to allow non-state agencies to participate in the public task of policing (Fuchs 2005).

International comparative studies show that Austria's culture places great emphasis on the values of collectivism and solidarity (Hofstede et al. 2010). In many respects these values contrast with neoliberal notions of individualism and the priority of competition and the market. For that reason, collective (state) solutions to security problems are usually preferred. In addition, security is often seen as a fundamental right of every citizen. As a result, privatisation that might result in an unequal distribution of security is seen as unacceptable (Öffentliche Sicherheit 2002, Bundeskanzleramt 2013). On the other hand, however, the emphasis on (internal) solidarity is quite often explicitly associated with the exclusion of those who are non-members of Austrian society, such as migrants (Bundeskanzleramt 2013, p. 4).

In this view, public and private are defined as fundamentally different domains, with the absolute necessity to preserve a clear distinction between them. Any form of hybridisation or in-between 'grey zone' is viewed as impermissible (Öffentliche Sicherheit 2002). This implies that the neoliberal assumption that the state is responsible for steering and that other (private) agencies may do the rowing (Osborne and Gaebler 1993) is generally not accepted in Austria. This is also related to the special trust attributed to state officials with their positions of general interest: 'Public-legal powers may only be used by officers of public services with a special relation of trust' (Öffentliche Sicherheit 2002).

Fuchs $(2005,2012)$, one of the few researchers in Austria who has published on plural and private policing, notes that the state's monopoly of violence, although a fundamental principle, especially in Austria, provides an unsatisfactory line of demarcation between the public and the private in policing. In his view, Austrian private security companies do not intend to change this monopoly. For that reason, he proposes a somewhat different line of demarcation. Following a widespread belief in Austria, in his view the state's principle task is to guarantee security to all citizens. This implies that security cannot be left completely to other agencies. However, under certain circumstances it may be acceptable that private actors participate in policing. According to Fuchs, four conditions are relevant to understanding why in certain (most?) situations only the state should be responsible for policing. First, if there are conflicting interests, a neutral agency should be responsible for policing. Private agencies are seen as incapable of being neutral. Secondly, if an intervention is necessary based on certain capacities such as the use of coercion, only the state should do this, because only the state has such resources at its disposal. Thirdly, if there is a special need for legitimation of policing, the state should be responsible for policing. Finally, the state should be responsible for policing if citizens have a special need for the protection of their rights.

Although Fuchs' analysis is much more sophisticated than the analysis founded on the monopoly of violence, in the end it does not provide a fundamentally different perspective on the relations between public and private in policing. The state is still seen as superior to other actors. In general, the conclusion is that policing should be left to the state.

In Austria the dominance of the state and of constitutional-legal perspectives is so powerful that even representatives of the private security industry may feel compelled to subscribe to the principle that any activity that is related to the use of coercion must remain in the power of the state. Illustrative is the statement of a representative of G4S Austria: 'The state's monopoly of violence should remain intact and the cooperation with the state agencies "transparent and clear": we do not want "grey zones"' (Öffentliche Sicherheit 2002). In other words, in Austria, the new markets for private security are quite marginal, even in the perception of the private security industry itself.

\section{Concluding remarks}

The preceding analysis shows that there are important differences between Canada - Ontario and Austria in the dominating discourses about plural policing. These differences reflect significant 
distinctions in the political and cultural context, related to dominant views on the role of the state, the perceived division of responsibilities with other (private) agencies, and the establishment and impact of neoliberalism. These views are translated in different sets of values to assess the pluralisation of policing and its (potential) impact.

The main differences between the two countries can be summarised as on the one hand a discourse built on the notion of the public good in Canada, as opposed to a discourse in Austria centred on the constitutional state. Both countries have their debates on plural policing, but these are framed in different terms in each country. In Canada the debate is mainly about different interpretations of the public good (value for money versus serving the community and/or democratic accountability). In Austria it is about different arguments to maintain a central role for the state in policing and security (for instance, the monopoly of violence in contrast with fundamental tasks of the police in security).

The main differences between the two discourses may be recapitulated as follows (see also Figure 1). In contrast to Canada, where the neoliberal discourse gained a strong position in policing and security, in Austria this ideological view is quite marginal in this domain. As a result, in Austria the state has a taken-for-granted dominance (with different arguments underlying it, ranging from the monopoly of violence to fundamental state tasks in security and policing), whereas in Canada a distribution of responsibilities in policing and security is much more widely accepted (although the lack of democratic accountability of the private sector is criticised). This also results in different views on the role of the state. In contrast to Canada, in Austria, for fundamental reasons, the state should not only be involved in steering, but also in 'rowing' (although it is not common to use such terms). While hybrid forms of policing and security (with diverging contributions of both public and private agencies) are usually perceived positively in Canada, this sort of hybridisation is not accepted in Austria ('no grey zones' is the way it is often stated). This is a consequence of the strict and fundamental distinction made between public and private in policing and security. In Austria the discourse on policing depends strongly on the historical context and tradition. Continuity and risk aversion are much more appreciated than the room to terminate contracts and relations to improve effectiveness and efficiency, values that predominate in Canada. The strong external orientation in Canada towards markets and the needs of citizens defined as customers, contrasts sharply with the Austrian emphasis

\begin{tabular}{|c|c|}
\hline Canada-Ontario & Austria \\
\hline $\begin{array}{l}\text { a. dominance of neoliberal arguments and } \\
\text { views } \\
\text { b. less dominant position of the state; taken- } \\
\text { for-granted distribution of responsibilities } \\
\text { across a range of agencies } \\
\text { c. state as a contracting agency in policing } \\
\text { and security } \\
\text { d. public-private partnerships, contract } \\
\text { policing } \\
\text { e. emphasis on effectiveness and efficiency, } \\
\text { with resistance against business values in } \\
\text { the workplace and call for democratic } \\
\text { accountability } \\
\text { f. external orientation (notions of business } \\
\text { and market, needs of customers, etc.) } \\
\text { g. orientation on service and quality }\end{array}$ & $\begin{array}{l}\text { a. marginal position of neoliberal arguments } \\
\text { in policing and security policy } \\
\text { b. taken-for-granted dominance of the state } \\
\text { (monopoly of coercion; fundamental tasks } \\
\text { of the state in security) } \\
\text { c. state not only 'steering', also 'rowing' in } \\
\text { policing and security } \\
\text { d. no hybridization (no 'grey zones'; belief } \\
\text { in strict distinction between public and } \\
\text { private) } \\
\text { e. emphasis on historical roots, tradition, and } \\
\text { continuity } \\
\text { f. legal perspective (constitutional } \\
\text { considerations; legal notions about state } \\
\text { tasks, human rights) } \\
\text { g. orientation fundamental rights and } \\
\text { legality }\end{array}$ \\
\hline
\end{tabular}

Figure 1. Contrasts between dominant discourse on (plural) policing in Canada - Ontario and Austria. 
on legal principles and constitutional considerations. Critical views are also sounded in Canada on the impact and consequences of plural policing, mainly framed in terms of quality of service to the community and/or the lack of democratic accountability. Other notions are considered to be much more fundamental in Austria, such as the constitutional position of the state and the monopoly of violence.

Our comparative analysis highlights the importance of historical, cultural, emotional and political factors in understanding the pluralisation of policing. What we have tried to show is that certain concepts which are often used in the study of (plural) policing and perceived as universal, such as the public good, are in fact strongly context dependent. In dominant theoretical approaches as the nodal governance of security (Wood and Shearing 2007), the tendency to consider policing as an economically public good is firmly based on the suggestion of a universal relevance of neoliberalism and an Anglophone world view (Terpstra 2015). Reasoning in terms of economically public goods rather seems to be an example of a peculiar way of Anglo-Saxon theorising which takes the colonisation of the police and criminal justice sectors by 'free market forces' as self-evident. This reasoning largely disregards that 'value for money'-policies elicit 'local' forms of resistance and various forms of renewed state regulation.

We contend that these dominant approaches have strongly contributed to the tendency in police science towards 'de-contextualisation'. Admittedly, nodal governance theories seem to adhere to local contexts ('local capacity governance'), but the authors conceive the neoliberal shift 'away from the state' as an 'inevitable' universal development (for example, Shearing and Wood 2003, p. 411). By means of this de-contextualising, police science, probably without being aware of it, may operate as a trigger or vehicle for a world-wide transfer of Anglophone police models and strategies, without realising why these models and strategies may not fit in with local traditions, values and perspectives.

Our analysis may also have important consequences for international comparative studies. As mentioned before, Nelken (2002) demanded attention for the main question in international comparative research: how can we be sure that we are comparing 'like with like', in other words avoid comparing chalk with cheese without being aware of it. In many international comparative studies this is not only a problem at the analytic and descriptive level. Such studies often also have an evaluative component, in which case it is important to realise that the normative standards for the evaluation may also be highly context dependent. If evaluation is based on the assumption that evaluation standards are universal and context-independent, the study will run the risk of imposing a normative standard that is out of place within the given cultural context.

\section{Notes}

1. These countries were selected on the basis of the following criteria. First, each country should have a minimum level of plural policing. Secondly, the selected countries should have significant differences in plural policing. However, considerable differences in social, political and economic context would make comparison between jurisdictions difficult or even almost senseless. For this reason, countries like South Africa have not been considered.

2. For a clarification of research methods, see Terpstra et al. (2013).

\section{Disclosure statement}

No potential conflict of interest was reported by the authors.

\section{References}

Beller, S., 2006. A concise history of Austria. Cambridge: Cambridge University Press.

Blasi, W., 2015. Der bedrohte Staat. Über rivalisierende Wehrverbände, ein ausgehöhltes Gewaltmonopol und die latente Bürgerkriegsgefahr in der Ersten Republik. SIAK-Journal Zeitschrift für Polizeiwissenschaft und polizeiliche Praxis (2), 8497. 
Bundeskanzleramt, 2013. Österreichische Sicherheitssstrategie. Sicherheit in einer neuen Dekade - Sicherheit gestalten. Wien: Bka.

Bundesministerium für Inneres, 2015. Innen-Sicher 2015: Für Sicherheit, für Österreich. Wien: BMI.

Burbidge, S., 2005. The governance deficit: reflections on the future of public and private policing in Canada. Canadian journal of criminology and criminal justice, 47 (1), 63-86.

Carroll, E., 2004. The blurring of public police and private agencies. Mississauga: Policing \& Security Consulting Services.

Clark, D., 2002. Neoliberalism and public service reform: Canada in comparative perspective. Canadian journal of political science [Revue canadienne de science politique], 35 (4), 771-793.

CoESS, 2011. Private security services in Europe. Facts \& figures 2011. Wemmel: CoESS.

Crawford, A., 2006. Policing and security as 'club goods': the new enclosures? In: J. Wood and B. Dupont, eds. Democracy, society and the governance of security. Cambridge: Cambridge University Press, 111-138.

Cukier, W., Quigley, T., and Susla, J., 2003. Canadian regulation of private security in an international perspective. International journal of the sociology of law, 31 (3), 239-265.

De Lint, W., 1999. A postmodern turn in policing: policing as pastiche? International journal of the sociology of law, 27, 127-152.

Esping-Andersen, G., 1990. The three worlds of welfare capitalism. Oxford: Polity Press.

Expert Panel on the Future of Canadian Policing Models, 2014. Policing Canada in the 21st century: new policing for new challenges. Ottawa: Council of Canadian Academies.

Fuchs, W., 2005. Private Sicherheitsdienste und öffentlicher Raum. Ein Überblick über die öffentlichen-rechtlichen Rahmenbedingungen in Österreich mit rechtstaatsächlichen und kriminologischen Anmerkungen. Innsbruck: Universität Innsbruck.

Fuchs, W., 2012. Sicherheit als faszinierendes Geschäftsvehikel? Zur Effektivität kommerzieller und staatlicher Sicherheitsarbeit. SIAK-Journal Zeitschrift für Polizeiwissenschaft und polizeiliche Praxis (1), 62-75.

Gattinger, M. and Saint-Pierre, D., 2010. The 'neoliberal' turn in provincial cultural policy and administration in Quebec and Ontario: the emergence of 'quasi-neoliberal' approaches. Canadian journal of communication, 35 (2), $279-302$.

Harvey, D., 2005. A brief history of neoliberalism. Oxford: Oxford University Press.

Hermer, J., et al., 2005. Policing in Canada in the twenty-first century: directions for law reform. In: D. Cooley, ed. Re-imagining policing in Canada. Toronto: University of Toronto Press, 22-91.

Hofstede, G., Hofstede, G.J. and Minkov, M., 2010. Cultures and organizations: software of the mind. New York: McGraw-Hill.

Jones, T. and Newburn, T., 2006. Understanding plural policing. In: T. Jones and T. Newburn, eds. Plural policing: a comparative perspective. London: Routledge, 1-11.

Kinnear, D., 2000. Privatization: a threat to public police and the public good. In: J. Richardson, ed. Police and private security: what the future holds. Ottawa: Canadian Association of Chiefs of Police, 108-116.

Kreisky, E., 2002. Neoliberale Praktiken und rechtspopulistische Regulierung sozialen Protestst: Anlassfall Österreich. Vortag 27 Mai 2002, in Zuge der Vorlesung Neoliberalismus, Staat und Geslecht. Wien: Universität Wien. Available from: http:// homepage.univie.ac.at/marion.loeffler/archiv/SS02/VO_07.pdf [Accessed October 2015].

Law Commission of Canada, 2006. In search of security: the future of policing in Canada. Ottawa: Law Commission of Canada.

Lithopoulos, S. and Rigakos, G., 2005. Neo-liberalism, community, and police regionalization in Canada: a critical empirical analysis. Policing: an international journal of police strategies \& management, 28 (2), 337-352.

Loader, I., 2000. Plural policing and democratic governance. Social \& legal studies, 9 (3), 323-345.

Loader, I. and Walker, N., 2007. Civilizing security. Cambridge: Cambridge University Press.

Marks, M., 2007. Police unions and their influence: subculture or counter-culture? In: M. O'Neill, M. Marks and A.-M. Singh, eds. Police occupational culture (sociology of crime, law and deviance, volume 8). Emerald Group Publishing Limited, 229-251.

McDonough, P., 2006. Habitus and the practice of public service. Work employment and society, 20 (4), 629-647.

Murphy, C., 1998. Policing postmodern Canada. Canadian journal of law and society, 13, 1-25.

Murphy, C., 2002. The rationalization of public policing in Canada: a study on the impact and implications of resource limits and market strategies in public policing. The Police Future Group, CACP, Electronic Series No. 1.

Murphy, C. and Clarke, C., 2005. A study of policing and security in two Canadian communities. In: D. Cooley, ed. Re-imagining policing in Canada. Toronto: University of Toronto Press, 209-259.

Murray, T., 2004. The Canadian police executive community and its pressures. The Canadian review of policing research, 1. Available from: http://crpr.icaap.org/index.php/crpr/article/view/6/6

Murray, T. and McKim, E., 2000. Introduction: the policy issues in policing and private security. In: J. Richardson, ed. Police and private security: what the future holds. Ottawa: Canadian Association of Chiefs of Police, 1-14.

Nelken, D., 1994. Whom can you trust? The future of comparative criminology. In: D. Nelken, ed. The futures of criminology. London: Sage, 220-243.

Nelken, D., 2002. Comparing criminal justice. In: M. Maguire, R. Morgan and R. Reiner, eds. The Oxford handbook of criminology (3d rev. ed.). Oxford: Oxford University Press, 175-202.

Nelken, D., 2010. Comparative criminal justice: making sense of difference. Los Angeles, CA: Sage. 
Nelken, D., 2011. Afterword: studying criminal justice in globalising times. In: D. Nelken, ed. Comparative criminal justice and globalization. Farnham: Ashgate, 183-210.

Newburn, T., 2001. The commodification of policing: security networks in the late modern city. Urban studies, 38 (5-6), 829-848.

O'Connor, D. and Ilcan, S., 2005. The folding of liberal government: contract governance and the transformation of the public service in Canada. Alternatives: global, local, political, 30 (1), 1-23.

Öffentliche Sicherheit, 2002. Privatisierung Öffentlicher Sicherheitsdienstleistungen. Privat statt Staat. Wien: BMI (Öffentliche Sicherheit). Available from: http://www.bmi.gv.at/cms/BMI_OeffentlicheSicherheit/2002/11_12/Artikel_01.aspx.

O'Malley, P. and Hutchinson, S., 2007. Converging corporatization? Police management, police unionism, and the transfer of business principles. Police practice and research, 8 (2), 159-174.

Osborne, D. and Gaebler, T., 1993. Reinventing government. How the entrepreneurial spirit is transforming the public sector. New York: Plume.

Rauscher, H., 2011. Der Quatsch mit dem 'Neoliberalismus'. Der Standard, 24 Aug.

Rigakos, G., 2002. The new parapolice: risk markets and commodified social control. Toronto: University of Toronto Press.

Rigakos, G. and Leung, C., 2006. Canada. In: T. Jones and T. Newburn, eds. Plural policing: a comparative perspective. London: Routledge, 126-138.

Robertson, N., 2012. Policing: fundamental principles in a Canadian context. Canadian public administration, 55 (3), $343-$ 363.

Ruddell, R. and Jones, N.A., 2014. The economics of Canadian policing: five years into the great recession. Regina: Collaborative Centre for Justice and Safety, University of Regina.

Sandrisser, W., 2015. Das österreichischer Modell integrierter Sicherheitspolitik. Möglichkeiten und Probleme im gesamtstaatlichen Kontext. SIAK-Journal Zeitschrift für Polizeiwissenschaft und polizeilicher Praxis (10), 64-80.

Shearing, C., 2005. Nodal security. Police quarterly, 8 (1), 57-63.

Shearing, C. and Stenning, P., 1981. Modern private security: its growth and implications. In: M. Tonry and N. Morris, eds. Crime and justice: an annual review of research. Chicago, IL: The University of Chicago Press, 96-110.

Shearing, C. and Wood, J., 2003. Nodal governance, democracy, and the new 'denizens'. Journal of law and society, 30 (3), 400-419.

Stenning, P.C. and Shearing, C.D., 2005. Reforming police: opportunities, drivers and challenges. Australian and New Zealand journal of criminology, 38 (2), 167-180.

Stolzlechner, H. and Horvath, T., 2009. Sicherheitsverwaltung und Privatwirtschaft. Teil 1. SIAK-Journal Zeitschrift für Polizeiwissenschaft und polizeilicher Praxis (4), 67-81.

Stolzlechner, H. and Horvath, T., 2010. Sicherheitsverwaltung und Privatwirtschaft. Teil 2. SIAK-Journal Zeitschrift für Polizeiwissenschaft und polizeilicher Praxis (1), 17-36.

Tálos, E., 2001. Sozialpolitik zwischen konservativer Tradition und neoliberaler Orientierung. Kurswechsel. Zeitschrift für gesellschafts-, wirtschafts- und umweltpolitische Alternativen, 1, 17-29.

Tálos, E. and Fink, M., 2001. Der österreichische Wohlfahrtstaat: Entwicklung und Herausforderungen. New Delhi: Tagesbeitrag International Seminar on Welfare State Systems: Development and Changes. Available from: http:// www.demokratiezentrum.org/fileadmin/media/pdf/wohlfahrtsstaat.pdf [Accessed October 2015].

Terpstra, J., 2015. 'Not just one node among many' - plural policing in a state-dominated context: the case of Austria. Policing \& society. doi:10.1080/10439463.2015.1012169

Terpstra, J., van Stokkom, B., and Spreeuwers, R., 2013. Who patrols the streets? An international comparative study to plural policing. The Hague: Eleven.

Thomas, P.M. and Tufts, S., 2016. Austerity, right populism, and the crisis of labour in Canada. Antipode, 48 (1), $212-230$.

Van Swaaningen, R., 2011. Critical cosmopolitanism and global criminology. In: D. Nelken, ed. Comparative criminal justice and globalisation. Farnham: Ashgate, 125-144.

Wenda, G., 2013. Municipal police in Austria: history, status quo and future. SIAK-Journal Zeitschrift für Polizeiwissenschaft und polizeiliche Praxis (4), 51-62.

Wenda, G., 2014. Safety at the local level: examples from Austria. In: J. Czapska, ed. Koordynacja działań lokalnych na rzecz bezpieczeństwa. Cracow: WYDAWNICTWO, 380-395.

Wood, J., 2000. Reinventing governance: a study of transformations in the Ontario Provincial Police. Thesis. Centre for Criminology, University of Toronto.

Wood, J. and Shearing, C., 2007. Imaging security. Cullompton: Willan. 